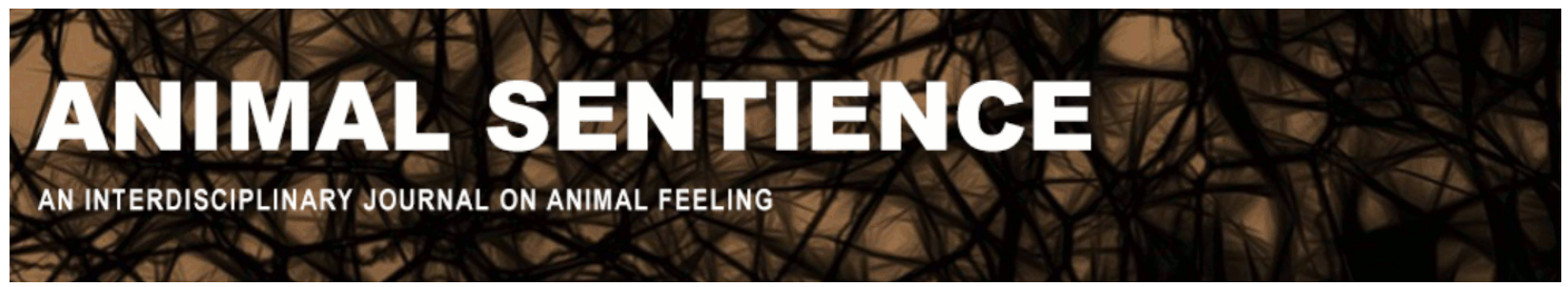

Bryant, Christopher J. (2020) Innovation in meat production: a problem and an opportunity. Animal Sentience 30(12)

DOI: $10.51291 / 2377-7478.1640$

Date of submission: 2020-09-05

Date of acceptance: 2020-09-05

(c)

This article has appeared in the journal Animal

Sentience, a peer-reviewed journal on animal

cognition and feeling. It has been made open access,

free for all, by WellBeing International and deposited

in the WBI Studies Repository. For more information,

please contact

wbisr-info@wellbeingintl.org.

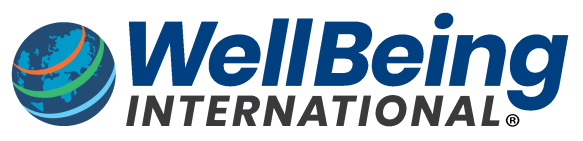

SOLUTIONS FOR PEOPLE, ANIMALS AND ENVIRONMENT 


\title{
Innovation in meat production: a problem and an opportunity
}

Commentary on Wiebers \& Feigin on Covid Crisis

\author{
Christopher Bryant \\ Department of Psychology, University of Bath
}

\begin{abstract}
Innovation in meat production has enabled modern humans to inflict far greater harm on animals, the environment, and public health than was possible just a few decades ago. Wiebers \& Feigin aptly express the urgency with which these issues must be addressed. Those advocating for animals on moral grounds face resistance from omnivores citing taste, price and convenience. Further innovation in meat production (plant-based and cultured meat) will enable us to preserve the experience of eating meat whilst phasing out the many problems caused by industrial animal farming.
\end{abstract}

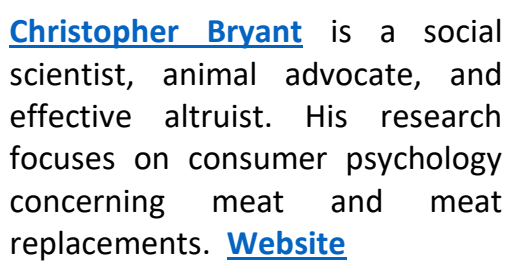

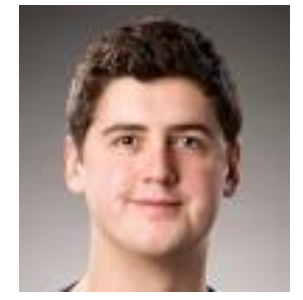

Wiebers \& Feigin's (2020) (W\&F) target article is a thorough and vivid analysis of the causal role of animal consumption in public health crises. W\&F not only elucidate the many public health problems in which the consumption of animal product is implicated, but they also aptly express the urgency of the problem.

The public health case against animal agriculture is indeed compelling. As W\&F point out, animal farming provides fertile breeding grounds for pathogens, creates the conditions for pathogens to mutate and jump to humans, exacerbates antibiotic resistance, and increases wild animal population density and proximity to humans by accelerating deforestation. The environmental case against animal farming is likewise stronger than ever (Poore \& Nemecek, 2018; IPCC, 2018; Willet et al., 2019).

It is important to communicate the environmental and public health evidence against animal agriculture to the large portion of the population who would otherwise lack the motivation to reduce their consumption of animal products. However, there is also a strong moral reason to stop industrial animal agriculture: We are needlessly breeding into existence billions of sentient beings only to inflict immeasurable suffering on them before slaughtering them for food. On most moral views, this is something we would want to avoid if it is not necessary.

If the moral case against farming pigs or cows for slaughter is unclear, it is instructive to reflect on doing the same with dogs. Dogs occupy a privileged position in Western cultures; most people consider their dogs part of the family (The Harris Poll, 2015). Yet pigs are even more intelligent than dogs (Broom, Sena \& Motnihan, 2009; Mendl, Held \& Byrne, 2010; Low et al., 2012); and dogs can just as easily be farmed for their meat - and are, in other cultures (Giordano, 2019; Li et al., 2017; Dugnoille, 2018). Pigs, like dogs, can experience joy and suffering, form relationships, and have a will to live (Marino \& Colvin, 2015). 
Unfortunately, the moral issues with industrial animal agriculture do not yet seem to be compelling for most people. In most developed countries, the proportion of people who eat meat is over $90 \%$ (Reinhart, 2018; Wunsch, 2019), and this presents a significant barrier to reasoning on this topic (Rothgerber, 2020). Many people appear to start with the conclusion that meat consumption is not immoral, and work backwards to arrive at whatever premises will lead there.

One encounters strong resistance when arguing against industrial animal agriculture on moral grounds. In the first draft of a recent paper, I had written that animals on factory farms 'suffer tremendously'. A reviewer suggested that 'The presented opinion should be more scientific and less emotional.' The published version no longer says that these animals 'suffer tremendously', but instead that they 'are kept in cages, routinely mutilated without painkillers, and painfully slaughtered' (Bryant, 2019). The reviewer requested no further changes.

We currently kill over 70 billion animals for food each year, and over $90 \%$ of farmed animals are on factory farms (Sentience Institute, 2019). No nonhuman animal in the wild caninflict suffering at this scale; neither could humans just a few decades ago. Modern human innovations and ingenuity have enabled us to create systems that inflict prolonged and intense suffering on an unimaginable number of animals with industrial efficiency every day. However, the same innovation and ingenuity may soon provide us with the means of stopping this (Anomaly, 2020; Bryant, 2020; Mancini \& Antonioli, 2020; Sha \& Xiong, 2020; Shapiro 2018; Tomiyama et al., 2020; Wurgraft 2019; Zhang et al. 2020).

As W\&F rightly argue, plant-based and cultured meat present an opportunity for humans to preserve the experience of eating meat without contributing to the moral, environmental, and public health ills associated with animal agriculture. There are psychological barriers to thinking clearly about this issue, especially motivated reasoning by the meat-eating majority. However, if we can produce the experience of eating meat without using animals, the motivation to justify their abuse will largely disappear. Governments, investors, and animal advocates should pay attention to these technologies; they may represent our best chance of ending industrial animal agriculture.

\section{References}

Anomaly, J. (2020) Cultured meat would prevent the next Covid crisis. Animal Sentience 30(5)

Broom, D. M., Sena, H., \& Moynihan, K. L. (2009). Pigs learn what a mirror image represents and use it to obtain information. Animal Behaviour, 78(5), 1037-1041.

Bryant, C. J. (2019). We can't keep meating like this: Attitudes towards vegetarian and vegan diets in the United Kingdom. Sustainability, 11(23), 6844.

Bryant, C. J. (2020). Culture, meat, and cultured meat. Journal of Animal Science 98(8) .

Dugnoille, J. (2018). To eat or not to eat companion dogs: symbolic value of dog meat and human-dog companionship in contemporary South Korea. Food, Culture \& Society, 21(2), 214-232. 
Giordano, C. (2019). Yulin Dog Meat Festival: Dogs blow-torched alive in footage from China. The Independent.

Intergovernmental Panel on Climate Change (2018). Global Warming of $1.5^{\circ} \mathrm{C}$.

Li, P. J., Sun, J., \& Yu, D. (2017). Dog "Meat" Consumption in China: A Survey of the Controversial Eating Habit in Two Cities. Society \& Animals, 25(6), 513-532.

Low, P., Panksepp, J., Reiss, D., Edelman, D., Van Swinderen, B., \& Koch, C. (2012, July). Cambridge Declaration on Consciousness. Francis Crick Memorial Conference. Cambridge, England (pp. 1-2).

Mancini, M. C., \& Antonioli, F. (2020). To What Extent Are Consumers' Perception and Acceptance of Alternative Meat Production Systems Affected by Information? The Case of Cultured Meat. Animals 10(4): 656.

Marino, L., \& Colvin, C. M. (2015). Thinking pigs: A comparative review of cognition, emotion, and personality in Sus domesticus. International Journal of Comparative Psychology 28

Mendl, M., Held, S., \& Byrne, R. W. (2010). Pig cognition. Current Biology, 20(18), R796R798.

Poore, J., \& Nemecek, T. (2018). Reducing food's environmental impacts through producers and consumers. Science, 360(6392), 987-992.

Reese, J. (2019, April 11). US Factory Farming Estimates.

Reinhart, R. (2018). Snapshot: Few Americans Vegetarian or Vegan. Gallup.

Rothgerber, H. (2020). Meat-related cognitive dissonance: A conceptual framework for understanding how meat eaters reduce negative arousal from eating animals. Appetite, 146, 104511.

Sha, L., \& Xiong, Y. L. (2020). Plant protein-based alternatives of reconstructed meat: Science, technology, and challenges. Trends in Food Science \& Technology 102: 51-61

Shapiro, P. (2018). Clean meat: how growing meat without animals will revolutionize dinner and the world. Simon and Schuster.

The Harris Poll. (2015, July 16). More Than Ever, Pets are Members of the Family.

Tomiyama, A. J., Kawecki, N. S., Rosenfeld, D. L., Jay, J. A., Rajagopal, D., \& Rowat, A. C. (2020). Bridging the gap between the science of cultured meat and public perceptions. Trends in Food Science \& Technology 104: 144-152

Wiebers, David and Feigin, Valery (2020) What the COVID-19 crisis is telling humanity. Animal Sentience 30(1)

Willett, W., Rockström, J., Loken, B., Springmann, M., Lang, T., Vermeulen, S., ... \& Jonell, M. (2019). Food in the Anthropocene: the EAT-Lancet Commission on healthy diets from sustainable food systems. Lancet, 393(10170), 447-492.

Wunsch, N. (2019, May 20). Meat consumption and vegetarianism in Europe - Statistics and Facts. Statista.

Wurgaft, B. A. (2019). Meat planet: Artificial flesh and the future of food (Vol. 69). Univ of California Press.

Zhang, G., Zhao, X., Li, X., Du, G., Zhou, J., \& Chen, J. (2020). Challenges and possibilities for bio-manufacturing cultured meat. Trends in Food Science \& Technology 97: 443-450. 